\title{
多筒式電極誘起気泡による二次元試薬インジェクション
}

\section{Two-dimensional reagent-laden bubble injection by arrayed electrodes}

\author{
○学 神林卓也（芝浦工業大学） 学 濱野洋平（芝浦工業大学）＼cjkstart正 山西陽子（芝浦工業大学, JST さきがけ）
}

\begin{abstract}
Takuya KAMBAYASHI, Shibaura Institute of Technology, 3-7-5, Toyosu,Koto-ku, Tokyo Yohei HAMANO, Shibaura Institute of Technology Yoko YAMANISHI, Shibaura Institute of Technology, JST PRESTO

This paper present two-dimensional micro-chip for electrically-induced bubble injection device. The study is targeting to have electrodes which are patterned and integrated in the limited space to eject high-speed mono-dispersed bubbles for two dimensional processing of soft materials or patterning regent. For the present study, fundamental processing method to fabricated two-dimensional chip is presented. The novelty of injection mechanism, which is produced by the closed space at the tip of the electrode, is fabricated by original packaging techniques. Multiple injections of high-speed bubbles in microfluidic chip provide efficient high-density injection. This study will contribute to two-dimensional or three-dimensional injection techniques in the limited space for gene therapy and other biomedical applications.
\end{abstract}

Key Words: micro-nano bubbles, two-dimensional chip, biomedical applications

\section{1. 緒言}

近年遺伝子工学や再生医療の発展とともに, より高効率な 遺伝子インジェクション技術が求められている. 遺伝子導入 方法には従来ウイルス等を用いたインジェクション方法や リポソーム等を用いた化学的インジェクション方法などが あるが, 安全かつ局所的に高効率に導入できる技術は限られ ている. 一方, 物理的な遺伝子導入技術には電界を利用した 電気穿孔法, 超音波を利用したソノポレーションやパーティ クルガン法などあるが，高精度・高効率・低侵襲を満たす方 法には至っていない. 本研究室では電解質溶液中で水中放電 によって生じる気泡の界面の圧壊やその圧力波によって細 胞の局所アブレーションをする原理を基盤として[1], その外 側同心軸に溶液供給構造をつけて試薬をまとった気泡を細 胞内に導入するインジェクションメスの作製を行ってきた [2].インジェクションメスはマイクロガラス電極先端に有す る微小空間に放電をすることにより液体で満たされた空間 内に急激な圧力変動を生じることによって指向性を有する 気泡列が生じ, 狙った箇所にインジェクションできる利点が ある。しかし，従来のインジェクションメスは気泡列が一列 だけ生じるために局所的なインジェクションのみが可能で あり，広範囲に対して同時にインジェクションすることは不 可能である。また，三次元であるがゆえに，小型化・集積化 が困難であった，遺伝子治療などの分野においては，広範囲 に決められた場所に高効率にインジェクションする技術が 求められており, 遺伝子の次元パターニング等を行うことで より効果的な治療を見込める. そこで本研究ではガラス基板 上に多筒式電極誘起によるインジェクションメスを作製し， 細胞にインジェクションすることで従来のインジェクショ ンメスと穿孔能力を比較・評価することを目的とした.

\section{2. 多筒式インジェクションチップの作製}

2-1 多筒式電極誘起インジェクションチップコンセプト 本デバイスはガラス基板上に複数の電極を配置すること で同時に気泡列を生じさせることをコンセプトとしている.

（図 1).ガラス基板に複数の 2 次元電極を配し，2 次元流路 内に気泡列を発射し，これまで 3 次元形状では困難であった 多筒式インジェクションを可能にするものとする. 2 次元 チップ化することにより数多くの電極を集積化可能となり, 局所面積に高密度にインジェクションすることが可能とな る。本実験においては上記 2 次元インジェクション機構の基
礎実験として、2 次元チップ内における単一電極のインジェ クションを可能とした。

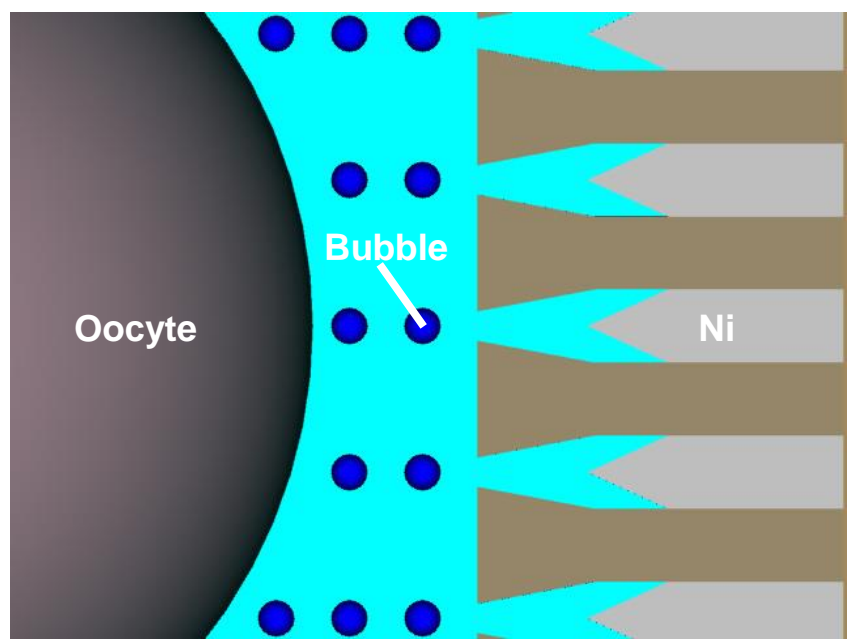

Fig.1 Concept of electrically-induced bubble injection by multiple electrodes in two-dimensional chip

\section{2-2 作製プロセス}

作業手順は次のようになり，プロセス図を図 2 に示す。ガ ラス基板に OAP を塗布し HMDS 処理を行った後に, スパッタ リングにより $\mathrm{Au}$ 膜を作製した。作製した $\mathrm{Au}$ 膜の上に OFPR-800LB を塗布し, フォトリソグラフィ及びウェットエッ チングを行うことで不要な $\mathrm{Au}$ 膜を取り除き通電部を作製し た. その後 SU-8 3025 でフォトリソグラフィによりインジェ クションメスの外形を作製した．最後に Ni を電気めっきに よりめっきすることで電極を作製し, PDMS でパッケージング を行った.

\section{2-3 チップ作製}

以上の手法で作製したデバイスを図 3 に示寸. SU-8 3025 でインジェクションメスの外形を作製する際に、1500rpm で 30 秒間スピンコートした後にプリベークし, 露光・現像を行 い，厚さを $50 \mu \mathrm{m}$ とした. 作製したチップ内にあるインジェ クションメスの口径は $50 \mu \mathrm{m}$ である. Ni を電気めっきする 際は電極の高さが $50 \mu \mathrm{m}$ となるようにめっき(電流密度 : 2 $\left.\mathrm{A} / \mathrm{dm}^{2}\right)$ した. 


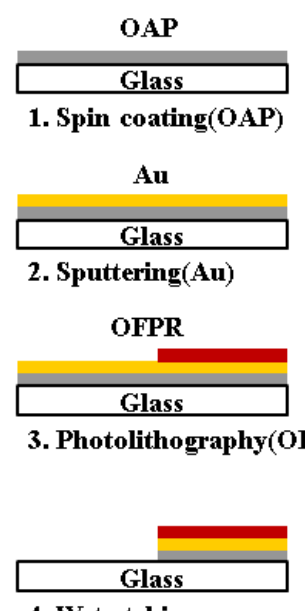

4. Wet etching

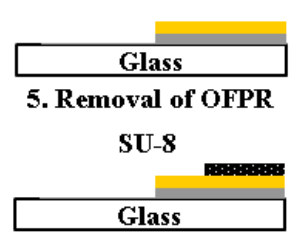

6. Photolithography (SU-8)

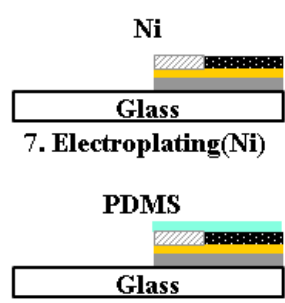

8. Sealing(PDMS)

Fig.2 Process flow to fabricated two-dimensional chip

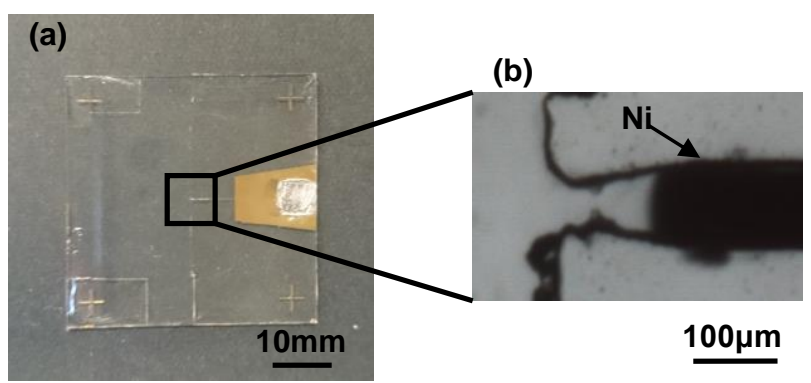

Fig.3 Two-dimensional micro-chip

(a)overall image (b)magnified view around electrode

\section{2-4 実験システムセットアップ}

作製したチップは図 4 に示寸ように対向電極と電解質溶液 を貯めるプールを設けたプラットフォームに組み込むこと で実験を行う。実験システムの概略図を図 5 に示す。電源は 電気メス用パルス電源（ConMed 社 Hyfrecator2000）を使用 した.このデバイスはアウトプット周波数 $450 \mathrm{kHz}$ ，インピー ダンスマッチングのためのサンプリング周波数は $450 \mathrm{kHz}$ で あり，3.5kHz でフィードバックを行っている. 実験に使用し た電解質溶液は $\mathrm{NaCl}$ 溶液 $(5 \%)$ である。

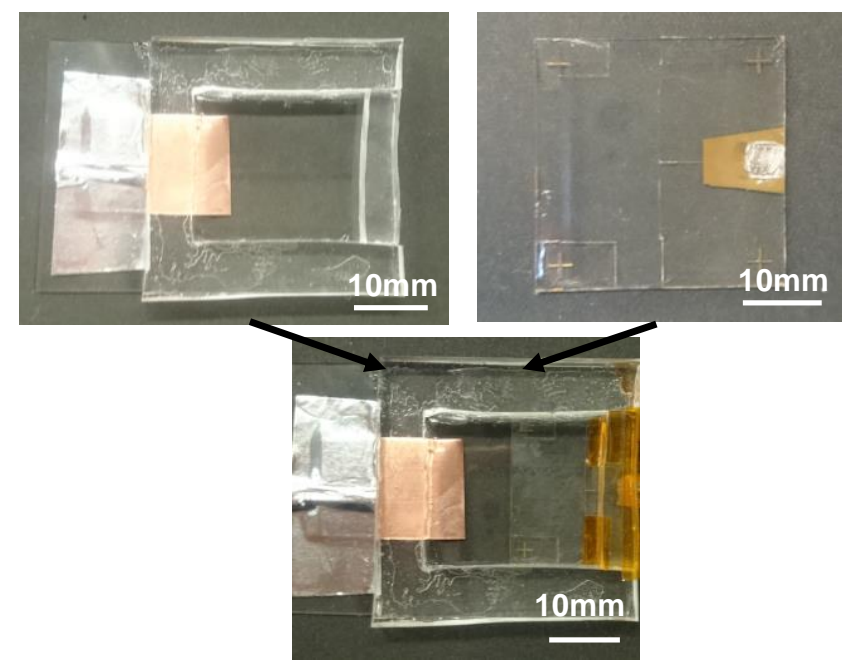

Fig.4 Fabricated two-dimensional microchip

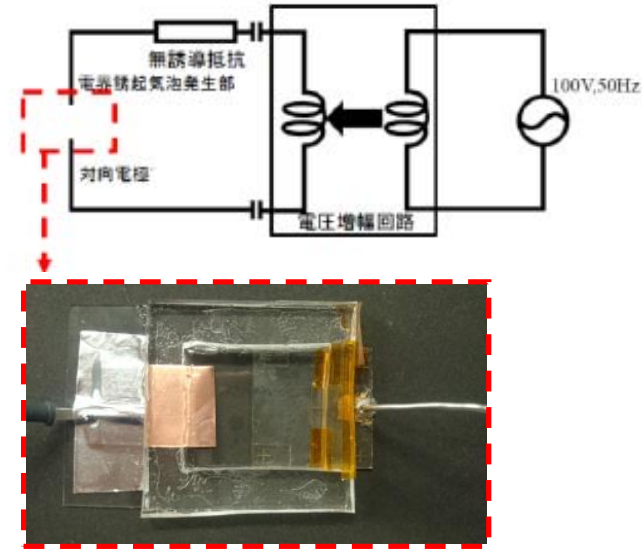

Fig. 5 Experimental setup

\section{3. 気泡の生成実験}

作製した 2 次元チップを用いて気泡の生成実験を行った. 図 6 に生成した気泡を示寸. 時間とともに液中放電により成 長した気泡が 2 次元チップ内に打ち出される様子を確認した。 本実験での条件は電気入ス用パルス電源の出力が 35 W 際に 生成されたものである. 気泡の大きさは約 $100 \mu \mathrm{m}$ である.
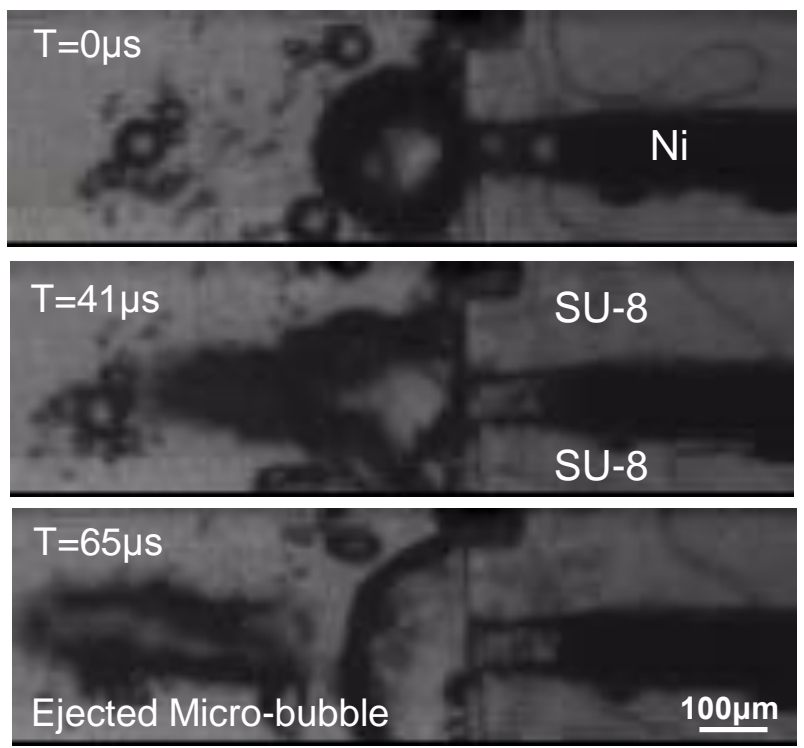

Fig. 6 Sequence photos of ejected micro-bubble (High-speed camera, 120,000fps)

\section{4. 結言}

本研究では 2 次元インジェクション機構の基礎実験として, 2 次元チップ内における単一電極の気泡生成を可能とした. 今後の課題として, 今回の単一電極による気泡を用いること で細胞にインジェクションし, 従来の三次元インジェクショ ンメスと穿孔能力を比較・評価することがあげられる. また, 多極式電極誘起にする場合の電極間距離やメスのサイズの 評価があげられる。

\section{謝辞}

本研究は文科省科研費（25289059，25630091）及び JST さき がけの助成を得て行われた。

引用文献

[1]Y. Yamanishi et al., IEEE Nanotechnology Magazine, Vol.6, No.2, pp.20-24, (2012).

[2] H. Kuriki, et al., Proc. of MicroTAS2013, pp.1173-1175, (2013). 